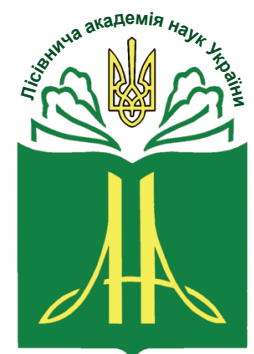

Forestry Academy of Sciences of Ukraine

Наукові праці Лісівничої академії наук України Proceedings of the Forestry Academy of Sciences of Ukraine

http://fasu.nltu.edu.ua https://doi.org/10.15421/412029

Article received 2020.04.02

Article accepted 2020.12.28
ISSN 1991-606X print

ISSN 2616-5015 online

@ $₫$ Correspondence author

Iurii Debryniuk

debrynuk_ju@ukr.net

General Chuprynka str., 103, Lviv, 79057, Ukraine

\title{
Pseudotsuga menziesii (Mirb.) Franco як перспективний деревний вид для плантаційних лісових насаджень західного регіону України
}

\author{
Ю.М. Дебринюк ${ }^{1}$
}

Pseudotsuga menziesii є інтродуцеентом з яскраво вираженою специифікою росту - порівняно повільноросла у молодому віці, але з наступним зростанням швидкості росту і підтриманням його високої інтенсивності впродовж тривалого періоду часу - до ста і більше років.

У молодих насадженнях до 25-30-річного віку псевдотсуга поступається за інтенсивністю росту ялині $i$ особливо - модрині. При цзьому перевага модрини за висотою та діаметром може складати два рази $і$ більше. Якщуо в чистих культурах псевдотсуга росте за I ${ }^{a}-I^{b}$ класами бонітету, в дубово-дугласієвих - за I ${ }^{a}$, в дугласієвоялинових - за I, то в дугласієво-модриново-ялиновому - за II класом бонітету, тоді як ялина росте за $I^{b}$, а модрина - за I і вище класами бонітету. Після 35-річного віку псевдотсуга нарошує темпи росту $і$ відставання ї за середніми таксаиійними показниками від модрини та ялини зменшується.

Для 35-річного віку в мішаних культурах за 60\%-ої участі в складі, близьким до оптимального розміщення дерев дугласії можна вважати $4 \times 3$ м; при ц̧ьому відбувається добре очищення стовбурів від сучків, формування компактної крони за середньої ї̈ площчі в межах 12-15 $\mathrm{M}^{2}$.

Після 35-річного віку і за участі в складі більше 60\% дугласія суттєво нарощує інтенсивність росту $і$ збільшення ї̈ густоти в усіх досліджених насадженнях супроводжується збільшенням запасу стовбурової деревини.

При плантаційному лісовирощуванні Р. тепzіеsіi розраховувати на отримання значних запасів деревини до 30-40-річного віку не варто. Завдання полягає у подальшому вирошуванні насаджень в режимі оптимальної густоти, щьо забезпечить значне посилення інтенсивності росту деревного виду після вказаного віку, $і$ вже в період 50-60 років запаси деревини сягатимуть $700 \mathrm{M}^{3} \cdot 2 \mathrm{a}^{-1} \mathrm{i}$ більше.

Найвищих класів бонітету псевдотсуга Мензіса досягає у насадженнях 40-60-річного віку за різних початкових схем розміщзення садивних місиьь - 2,0-6,0 ×0,8-2,0 м.

Ключові слова: таксаиійні показники; хід росту; густота; участь в складі; плантаційні насадження; Західний Лісостеп; Прикарпаття.

Вступ. Псевдотсуга Мензіса або дугласія (Pseudotsuga menziesii Mirb. Franco) є важливим комерційним видом на світовому ринку деревини, у зв'язку з чим широко культивується як в ареальних, так і в позаареальних умовах, зокрема, в Свропі. Площа насаджень за участю дугласії на теренах Західної Свропи сягає більше, ніж 800 тис. га
(Meuer, 1953; Podrázský, Zahradník, Pulkrab, Kubeček, \& Peňa, 2013; Da Ronch, Caudullo, \& Rigo, 2016).

Найбільший досвід культивування псевдотсуги мають Великобританія, Іспанія, Франція, Німеччина, Нідерланди, Бельгія. На основі вивчення та узагальнення особливостей росту і продуктивнос-

Дебринюк Юрій Михайлович - академік Лісівничої академії наук України, академік-секретар ЛАН України, доктор сільськогосподарських наук, професор кафедри лісових культур і лісової селекції. Національний лісотехнічний університет України, вул. Генерала Чупринки, 103, м. Львів, 79057, Україна. Тел.: 032-235-30-12, +38-067-195-78-36. E-mail: debrynuk_ju@ukr.net ORCID: http://orcid.org/0000-0002-0994-349X 
ті породи відібрано низку перспективних провенієнцій, які успішно впроваджують у ліси Європи 3 урахуванням природно-кліматичних умов конкретного регіону (Bastien, Sanchez, \& Michaud, 2013). Окрім високої продуктивності, P. menziesii на відміну від ялини, достатньо добре переносить посухи, тому вид вважають перспективним для культивування у рівнинній частині Свропи, де, за кліматичними прогнозами, тривалість посушливих періодів зростатиме (Moser, Bachofen, Müller, Metslaid, \& Wohlgemuth, 2016).

Переваги дугласії за продуктивністю та стійкістю над аборигенними європейськими видами стали причиною подальшого розширення насаджень за участю цієї інтродукованої породи. Інша причина полягає у високій вартості деревини дугласії - приблизно на 25\% вища, ніж ялинової (Burgbacher, \& Greve, 1996). У більшості країн Європи P. menziesii сприймають як натуралізований вид, який заслуговує подальшого широкого впровадження в європейські ліси (Podrázský, Čermák, Zahradník, \& Kouba, 2013).

Зокрема, у Чехії і Словаччині дугласію часто культивують у вологих бучинах і субучинах. У 60-річному віці чисті культури мають запас 890, а мішані з ялиною у віці 70 років - $740 \mathrm{~m}^{3} \cdot \mathrm{ra}^{-1}$ за щорічного поточного приросту у $19 \mathrm{~m}^{3} \cdot \mathrm{ra}^{-1}$ ( ̌̌ Sika, \& Vinš, 1980). Встановлено відсутність негативного впливу псевдотсуги на фізико-хімічні властивості грунту, навіть у випадку створення монокультури (Kupka, Podrázský, \& Kubeček, 2013), що дуже важливо $з$ погляду запровадження плантаційного вирощування породи.

P. menziesii пред'являє відносно невисокі вимоги до забезпечення грунту поживними речовинами, прирівнюючись у цьому відношенні до ялини. Для розведення дугласії найбільш придатними є типи лісорослинних умов 3 помірними вологістю та забезпеченням поживними речовинами (Otto, 1972; Хмилевский, 1987). Позитивний вплив дугласії на грунт 3-під сільськогосподарських угідь відзначили V. Podrázský, J. Remeš, V. Hart, \& W. Moser (2009).

Поряд 3 цим, значний вплив на ріст дугласії має вологість грунту. Встановлено (Cole, Lindsay, Newton, \& Bailey, 2018), що успіх закладання плантації за участю Larix occidentalis та $P$. menziesii в північно-східному Орегоні значною мірою залежить від цього чинника. Обробка ділянки гербіцидами може збільшити доступність вологи для саджанців у сухі літні місяці, тим самим збільшуючи ймовірність їх виживання.

Досвід інтродукції P. menziesii в Україні свідчить про добру акліматизацію виду в умовах Карпатського регіону, Західного Лісостепу, Західного Полісся та Правобережного Лісостепу, де іiі культури досягають віку технічної стиглості на 20-30 років раніше, ніж сосни звичайної (Бродович, Шляхта, 1979; Хмилевский, 1987; Матяш, 1988). В Україні лісові культури дугласії представляють собою ефективний об'єкт для дослідження, оскільки існують ділянки штучних насаджень 60-140-річного віку, які умовно можна вважати закінченим продуктом людської праці (Дебринюк, 2003).

Псевдотсуга Мензіса є дуже перспективним видом для широкого лісокультурного випробування в умовах $C_{2}, C_{3}$ як у чистих насадженнях, так i в суміші 3 швидкорослими листяними породами (Дебринюк, 2003, 2018). 3 огляду на значну швидкорослість, високу біотичну стійкість, цінну деревину і порівняно просту технологію вирощування, цей вид має значну перспективу для культивування у лісових насадженнях 3 погляду нагромадження значних обсягів деревини за відносно короткий період часу.

В Україні насадження 3 перевагою у складі P. menziesii розповсюджені на площі близько 1000 га, а запас стовбурової деревини в них оцінюється в 230,5 тис. м $^{3}$ (Дебринюк, 2013). Найбільші площі насаджень псевдотсуги зосереджені у Закарпатській області - більше 85\% від загальної площі лісостанів породи в Україні. Псевдотсуга є породою мішаних деревостанів, які займають в Україні майже 92\% від загальної площі насаджень за їі переваги. Лісостани псевдотсуги у переважаючій більшості мають штучне походження (майже 98\%), в т.ч. і насадження найвищої продуктивності, що свідчить про повну натуралізацію дугласії в умовах України.

В умовах свіжих і вологих яличин та бучин за раціональної технології вирощування псевдотсуга Мензіса характеризується інтенсивним ростом, високою біотичною стійкістю, нагромаджує в 50-60-річному віці близько $800 \mathrm{~m}^{3} \cdot \mathrm{ra}^{-1}$ стовбурової деревини. У зоні букових лісів на північних, північно-західних і північно-східних схилах у віці 100 років насадження дугласії нагромаджують значні запаси стовбурової деревини - близько $2000 \mathrm{~m}^{3} \cdot \mathrm{ra}^{-1}$. (Дебринюк, 2003).

Математичне опрацювання результатів досліджень показало, що в умовах вологої ялицевої бучини, залежно від технології створення та формування дугласієвих насаджень, у 50-55 річному віці середній діаметр хвойної породи змінюється в межах 37-40 см, а середня висота - від 26 до 27,5 м, що відповідає $\mathrm{I}^{\mathrm{b}}-\mathrm{I}^{\mathrm{c}}$ класам бонітету (Дебринюк, 2011).

Аналіз результатів досліджень 3 культивування P. menziesii вказує на високу актуальність питання щодо удосконалення технології створення і вирощування швидкорослих насаджень у відносно багатих і багатих типах лісорослинних умов з урахуванням ii максимальної продуктивності та біотичної стійкості, а також як перспективного виду для плантаційного лісовирощування.

Об'єкти та методика досліджень. Об' $\epsilon$ кm дослідження - штучні насадження різних вікових груп за участю P. menziesii у грудових типах лісорослинних умов. Предмет дослідження - динаміка таксаційних показників $P$. menziesii залежно від типу лісорослинних умов, участі у складі, густоти та віку насадження. Мета досліджень - обгрунтувати доцільність створення плантаційних лісових насаджень за участю $P$. menziesii чистого або мішаного складу, встановити технологічні складові їх створення і вирощування. 
Досліджувані об'єкти розміщені на території лісового фонду державних лісогосподарських підприємств Західного Лісостепу і Карпатського регіону.

Для встановлення впливу технологічних складових на продуктивність лісових культур за участю псевдотсуги Мензіса використано загальноприйняті методики лісівничо-таксаційних досліджень iз закладанням пробних ділянок (ПД) у найхарактернішому місці досліджуваного насадження (Гірс, Маніта, Миронюк, Свинчук, Березівський, 2013).

Для вивчення особливостей ходу росту модельні дерева дугласії відбирали в групах особин сильного, середнього і слабкого росту (Калинин, 1983).

Тип і підтип лісорослинних умов, тип лісу для кожної пробної ділянки уточнювали за методиками типологічних досліджень (Остапенко, Ткач, 2002) з використанням напрацювань 3. Ю. Герушинського (1996).

Під час статистичного опрацювання експериментальних матеріалів застосовували методи варіаційної статистики (Горошко, Миклуш, Хомюк, 2004) і пакети програми Microsoft Excel.

Результати досліджень. Вивчали таксаційні показники P. menziesii у штучних насадженнях Західного Лісостепу, вплив густоти та участі виду у складі лісових культур на запас стовбурової деревини. На основі експериментальних досліджень отримано матеріал, який відображає основні аспекти росту і нагромадження деревини дугласії у насадженнях різного складу та віку.

Нагромадження стовбурової деревини дугласієвими насадженнями у лісорослинних умовах Західного Лісостепу та Карпатського регіону зумовлені як природно-кліматичними чинниками, так i технологією створення і вирощування таких насаджень, використанням садивного матеріалу різного походження. Проте, незважаючи на певну варіабельність таксаційних показників $P$. menziesii навіть у подібних типах лісорослинних умов, більшість дослідників (Бродович, Шляхта, 1979; Шляхта, 1991; Дебринюк, 2003) вказують на високу продуктивність насаджень у західному регіоні України за участю цього деревного виду. В окремих випадках зафіксовано навіть витіснення псевдотсугою ялини зі складу культур Прикарпаття і Карпат (Бродович, 1969; Дебринюк, 2011).

Високу продуктивність $P$. menziesii у рівнинних умовах західного регіону України відзначав В.М. Хмільовський (1987). Однак, за продуктивністю дугласія тут поступається модрині, меншою мірою - ялині і найкраще росте в чистих культуpax за умови своєчасного проведення доглядових рубок. Ялина має перевагу над псевдотсугою за діаметром та висотою в молодому віці, відповідно, на $37-43$ та 20-37\%, а модрина - в 2,0-2,1 рази (Дебринюк, 2013).

Продуктивність та збережуваність псевдотсуги значною мірою залежить від іiі походження, участі у складі лісових культур, схем і способів змішування, густоти на одиницю площі. Ці складові відіграють основну роль у формуванні таксаційних показ- ників породи. Тому важливо здійснити аналіз елементів технології створення та вирощування насаджень за участю $P$. menziesii зі встановленням найдоцільніших з них, придатних для використання під час запровадження плантаційного вирощування цього цінного деревного виду.

Більшість насаджень за участю P. menziesii у Західному Лісостепу створені в умовах свіжого груду (табл. 1). Тут дугласія до 30-річного віку росте переважно за I-I ${ }^{\mathrm{b}}$, в період 31-40 років - за I $\mathrm{I}^{\mathrm{a}} \mathrm{I}^{\mathrm{c}}$, 4150 - за I $\mathrm{I}^{\mathrm{d}}, 61-70$ - за I $\mathrm{I}^{\mathrm{b}} \mathrm{I}^{\mathrm{c}}$ класами бонітету. Високу швидкість росту дугласія зберігає навіть після 100-річного віку, де бонітет її насаджень не нижче Ic класу. Найвищих класів бонітету псевдотсуга досягає у насадженнях за початкового розміщення $3,0-6,0 \times 1,0-1,5 \mathrm{M}$.

У насадженнях до 30-річного віку середній показник збережуваності P. menziesii у лісових культурах знаходиться в межах 34-48\%. При цьому, найнижча збережуваність деревного виду виявлена у чистих культурах (26,1 та 31,7\%). Основні причини низької збережуваності деревного виду зумовлені негативним впливом на дугласію біотичних та антропогенних чинників.

Висока початкова густота лісових культур є причиною виникнення сильної конкуренції між рослинами, сильного прояву процесу диференціації з наступним вибиранням рубками догляду відсталих у рості екземплярів.

Найвищий показник збережуваності рослин виявлено у насадженнях за участю псевдотсуги на рівні $10-30 \%$. Початково рідке розташування дугласії у лісових культурах $€$ причиною відсутності виникнення гострих конкурентних взаємовідносин між особинами та зумовлює їх високу збережуваність у насадженні.

Рівномірне розміщення дерев навіть в перегущених деревостанах (напр., ПД-14, 1632 шт. га ${ }^{-1}$ ) може забезпечити відносно інтенсивний ріст псевдотсуги (I ${ }^{\mathrm{a}}$ бонітет) та нагромадження нею високих запасів деревини. Поряд 3 цим, густе розташування дерев зумовлює їх сильну диференціацію в рості, формування поверхневої кореневої системи і як наслідок - наявності вітровальних і сніговальних екземплярів у лісостані, чого ніколи не спостерігається у мішаних дугласієвих насадженнях і в чистих лісостанах дугласії нормальної густоти.

У насадженнях 31-40-річного віку середній показник збережуваності змінюється в межах 18$24 \%$. Найнижчу збережуваність дугласії (близько 4\%) виявлено у лісових культурах з дуже високою початковою густотою садіння (8,3 тис. шт. га ${ }^{-1}$, ПД-3ст), де значна кількість дерев породи випала зі складу культур внаслідок негативного впливу 3 боку конкурентоздатніших деревних видів. Найвищий показник збережуваності дугласії (25-35\%) зафіксовано за її початкового розміщення в культурах за схемою 5-6× 1-2 м.

У чистих культурах 41-50-річного віку збережуваність дугласії у лісових культурах становить 23$25 \%$ за початкового розташування рослин $3 \times 1 \mathrm{~m}$. 


\section{Лісівничо-таксаційні показники Pseudotsuga menziesii у лісових культурах}

Таблиия 1

\begin{tabular}{|c|c|c|c|c|c|c|c|c|c|c|}
\hline \multirow{2}{*}{$\begin{array}{c}\text { № } \\
\text { ПД; } \\
\text { вік, } \\
\text { років }\end{array}$} & \multirow{2}{*}{ 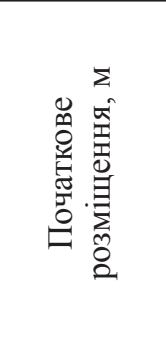 } & \multicolumn{2}{|c|}{$\begin{array}{c}\text { Кількість дерев } \\
\text { дугласії на } 1 \text { га, шт. }\end{array}$} & \multirow{2}{*}{ 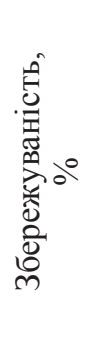 } & \multicolumn{2}{|c|}{$\begin{array}{c}\text { Середні } \\
\text { таксаційні показ- } \\
\text { ники дугласії }\end{array}$} & \multirow[b]{2}{*}{$\begin{array}{l}\text { Таксаційний } \\
\text { склад } \\
\text { насадження }\end{array}$} & \multirow[b]{2}{*}{ 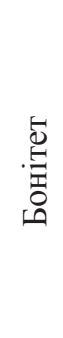 } & \multirow[b]{2}{*}{$\begin{array}{c}\mathrm{G} \\
\mathrm{M}^{2} \cdot \mathrm{ra}^{-1}\end{array}$} & \multirow[b]{2}{*}{$\begin{array}{c}\mathrm{M} \\
\mathrm{M}^{3} \cdot \mathrm{ra}^{-1}\end{array}$} \\
\hline & & 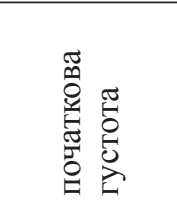 & 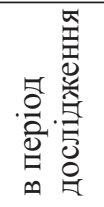 & & 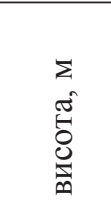 & 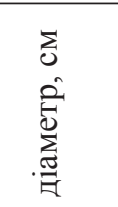 & & & & \\
\hline 1 & 2 & 3 & 4 & 5 & 6 & 7 & 8 & 9 & 10 & 11 \\
\hline \multicolumn{11}{|c|}{ Західний Лісостеп } \\
\hline \multicolumn{11}{|c|}{ Тип лісорослинних умов - $\mathrm{D}_{2}$} \\
\hline $\begin{array}{l}19 ; \\
27\end{array}$ & $\begin{array}{c}4,5 \times 0,6 \\
(1,5)\end{array}$ & 340 & 116 & 34,1 & 12,1 & 13,1 & $\begin{array}{c}1 \text { Пд5Дз } \\
2 \mathrm{M} є 2 \text { Гз }\end{array}$ & $\mathrm{I}^{\mathrm{a}}$ & 1,56 & 11 \\
\hline $\begin{array}{l}31 ; \\
25\end{array}$ & $\begin{array}{c}3,0 \times 0,7 \\
(1,0) \\
\end{array}$ & 200 & 96 & 48,0 & 14,7 & 16,7 & 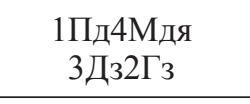 & $\mathrm{I}^{\mathrm{b}}$ & 2,10 & 21 \\
\hline $\begin{array}{l}55 \\
27\end{array}$ & $\begin{array}{c}3,0 \times 0,5 \\
(1,0)\end{array}$ & 320 & 135 & 42,2 & 14,5 & 17,6 & 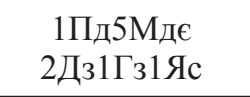 & $\mathrm{I}^{\mathrm{b}}$ & 3,30 & 28 \\
\hline $\begin{array}{l}54 \\
26\end{array}$ & $\begin{array}{c}3,0 \times 1,0 \\
(0,8)\end{array}$ & 300 & 132 & 44,0 & 13,6 & 15,6 & $\begin{array}{c}1,5 \Pi д 3,5 \\
\text { Мдг2Яс } \\
1 Д 31 Г з 1 Я с\end{array}$ & $\mathrm{I}^{\mathrm{b}}$ & 2,53 & 20 \\
\hline $\begin{array}{l}18 ; \\
27\end{array}$ & $\begin{array}{c}\text { не } \\
\text { встановл. }\end{array}$ & $\sim 250$ & 100 & $\sim 40,0$ & 15,1 & 18,1 & 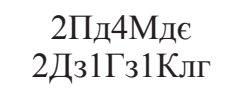 & $\mathrm{I}^{\mathrm{b}}$ & 2,58 & 24 \\
\hline $\begin{array}{l}2 ; \\
25\end{array}$ & $4,0 \times 0,7$ & 450 & 220 & 48,9 & 10,8 & 16,4 & 3Пд6Дз1Гз & I & 4,65 & 32 \\
\hline $\begin{array}{c}156 \\
26 \\
\end{array}$ & $\begin{array}{c}4,0 \times 0,8 \\
(0,45) \\
\end{array}$ & 1630 & 812 & 49,8 & 10,0 & 10,2 & $\begin{array}{c}\text { ЗПд3Д2,5 } \\
\text { Гз1,5Лп } \\
\end{array}$ & I & 6,60 & 40 \\
\hline $\begin{array}{l}12 ; \\
25\end{array}$ & $4,0 \times 0,7$ & 700 & 235 & 33,6 & 13,0 & 17,6 & 5Пд5Дз & $\mathrm{I}^{\mathrm{a}}$ & 5,73 & 45 \\
\hline $\begin{array}{c}157 \\
26\end{array}$ & $2,0 \times 0,8$ & 6250 & 1632 & 26,1 & 9,3 & 9,6 & 10Пд & II & 17,05 & 100 \\
\hline $\begin{array}{l}14 ; \\
27\end{array}$ & $1,5 \times 1,3$ & 5150 & 1632 & 31,7 & 13,6 & 15,9 & 10Пд & $\mathrm{I}^{\mathrm{a}}$ & 32,21 & 252 \\
\hline $\begin{array}{c}124 \amalg ; \\
31\end{array}$ & $1,0 \times 1,0$ & $\sim 40$ & 9 & $\sim 22,5$ & 14,3 & 12,7 & 9Ял1Мде + Пд & $\mathrm{I}^{\mathrm{a}}$ & 0,12 & 1 \\
\hline $\begin{array}{c}3 \mathrm{cr} ; \\
34\end{array}$ & $1,5 \times 0,8$ & 2700 & 101 & 3,7 & 16,4 & 19,9 & 1Пд5Дз4Клг & $\mathrm{I}^{\mathrm{a}}$ & 3,16 & 27 \\
\hline $\begin{array}{c}5 \mathrm{cr} \\
34 \\
\end{array}$ & $2,0 \times 1,0$ & 1500 & 480 & 32,0 & 11,9 & 11,6 & $\begin{array}{c}\text { 2Пд6Дз } \\
1 \text { Кля1Чш } \\
\end{array}$ & II & 5,09 & 31 \\
\hline $\begin{array}{l}4 \mathrm{cT} ; \\
35\end{array}$ & $\begin{array}{c}\text { не } \\
\text { встановл. }\end{array}$ & $\begin{array}{c}\text { не } \\
\text { встановл. }\end{array}$ & 216 & - & 15,5 & 18,1 & $\begin{array}{c}2 \text { 2Пд3,5Дз } \\
\text { 4,5Бк } \\
\end{array}$ & $\mathrm{I}^{\mathrm{a}}$ & 5,54 & 44 \\
\hline $\begin{array}{l}7 \mathrm{cr} \\
33\end{array}$ & $\begin{array}{c}2,0 \times 1,0 \\
(0,7)\end{array}$ & 1400 & 236 & 16,9 & 17,6 & 20,1 & $\begin{array}{c}\text { 3Пд4Бк } \\
1 \text { Кля } \\
1 \text { Влч1Гз }\end{array}$ & $\mathrm{I}^{\mathrm{a}}$ & 7,49 & 65 \\
\hline $\begin{array}{l}33 ; \\
36\end{array}$ & $6,0 \times 1,0$ & 550 & 75 & 13,6 & 24,4 & 34,9 & $\begin{array}{c}\text { 3Пд3Мдя } \\
\text { 2Лп2Гз }\end{array}$ & $\mathrm{I}^{\mathrm{d}}$ & 7,19 & 77 \\
\hline $\begin{array}{l}6 \Pi ; \\
39 \\
\end{array}$ & $6,0 \times 1,0$ & 550 & 190 & 34,5 & 23,8 & 34,6 & $\begin{array}{c}\text { 5Пд2Мде } \\
1 \text { 1Гз1Дз1Лп } \\
\end{array}$ & $\mathrm{I}^{\mathrm{c}}$ & 17,89 & 194 \\
\hline $\begin{array}{c}1 \mathrm{cT} ; \\
36\end{array}$ & $\begin{array}{l}5,0 \times 2,0 \\
\text { (по Пд) }\end{array}$ & 1000 & 214 & 21,4 & 21,4 & 29,8 & $\begin{array}{c}\text { 6Пд1Мдя } \\
1 \text { Кля1Яс1Дз }\end{array}$ & $\mathrm{I}^{\mathrm{c}}$ & 14,97 & 160 \\
\hline
\end{tabular}


Продовж. табл. 1

\begin{tabular}{|c|c|c|c|c|c|c|c|c|c|c|}
\hline 1 & 2 & 3 & 4 & 5 & 6 & 7 & 8 & 9 & 10 & 11 \\
\hline $\begin{array}{l}10 \\
34\end{array}$ & $\begin{array}{l}6,0 \times 1,0 \\
(\text { по Пд) }\end{array}$ & 1700 & 418 & 24,6 & 19,6 & 24,4 & $8 П д 2 Г з$ & $\mathrm{I}^{\mathrm{c}}$ & 19,53 & 195 \\
\hline $\begin{array}{l}6 \\
33\end{array}$ & $\begin{array}{c}\text { не } \\
\text { встановл. }\end{array}$ & $\begin{array}{c}\text { не } \\
\text { встановл. }\end{array}$ & 1263 & - & 15,1 & 18,6 & $\begin{array}{c}8 П д 10 \mathrm{Oc} \\
1 \text { Яс }\end{array}$ & $\mathrm{I}^{\mathrm{a}}$ & 34,52 & 272 \\
\hline $\begin{array}{l}13 \\
37\end{array}$ & $6,0 \times 1,0$ & 550 & 100 & 18,2 & 23,3 & 33,4 & 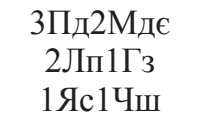 & $\mathrm{I}^{\mathrm{c}}$ & 8,80 & 92 \\
\hline $\begin{array}{c}8 \mathrm{ct} \\
45\end{array}$ & $3,0 \times 1,0$ & 1650 & 412 & 25,0 & 28,4 & 34,4 & $\begin{array}{c}9 \Pi_{д 0,5 \mathrm{C}_{3}} \\
0,5 \Gamma_{3}\end{array}$ & $\mathrm{I}^{\mathrm{d}}$ & 38,26 & 549 \\
\hline $\begin{array}{c}8 \mathrm{ct} \\
50\end{array}$ & $3,0 \times 1,0$ & 1650 & 378 & 22,9 & 29,8 & 38,9 & 9,5Пд0,5С3 & $\mathrm{I}^{\mathrm{d}}$ & 44,87 & 669 \\
\hline $\begin{array}{c}2 \mathrm{ct} \\
63\end{array}$ & $1,5 \times 1,0$ & 6700 & 383 & 5,7 & 30,4 & 43,2 & 10Пд & $\mathrm{I}^{\mathrm{b}}$ & 56,17 & 877 \\
\hline $\begin{array}{c}2 \mathrm{ct} \\
68\end{array}$ & $1,5 \times 1,0$ & 6700 & 298 & 4,4 & 32,1 & 44,6 & 10Пд & $\mathrm{I}^{\mathrm{c}}$ & 46,55 & 647 \\
\hline \multicolumn{11}{|c|}{ Тип лісорослинних умов - $\mathrm{D}_{3}$} \\
\hline $\begin{array}{c}63 \sigma \\
37\end{array}$ & $4,0 \times 1,0$ & 160 & 47 & 29,4 & 16,5 & 24,5 & $\begin{array}{c}\text { 1Пд3Мдя } \\
\text { 3Гз1Лп1Яс } \\
\text { 1Взш } \\
\end{array}$ & $\mathrm{I}^{\mathrm{a}}$ & 2,20 & 18 \\
\hline $\begin{array}{c}10 c \\
33\end{array}$ & $2,0 \times 1,5$ & $\sim 500$ & 124 & 24,8 & 18,8 & 18,1 & $\begin{array}{c}\text { 1Пд4Мдг } \\
2 \text { Ял2Лп1Яс }\end{array}$ & $\mathrm{I}^{\mathrm{b}}$ & 3,20 & 31 \\
\hline $\begin{array}{l}31 л ; \\
140\end{array}$ & $\begin{array}{c}\text { не } \\
\text { встановл. }\end{array}$ & $\begin{array}{c}\text { не } \\
\text { встановл. }\end{array}$ & 293 & - & 39,9 & 75,0 & 10Пд & $\mathrm{I}^{\mathrm{c}}$ & 129,49 & 2500 \\
\hline
\end{tabular}

Прикарпаття та Зовнішні Карпати

\begin{tabular}{ccccccccccc}
\hline \multicolumn{10}{c}{ Тип лісорослинних умов $-\mathrm{D}_{3}$} \\
\hline $\begin{array}{c}7 \text { буд; } \\
23\end{array}$ & $3,0 \times 0,8$ & 2400 & 1250 & 52,1 & 10,8 & 12,9 & $\begin{array}{c}\text { 7Пд2Ял } \\
1 \text { Яц }\end{array}$ & $\mathrm{I}^{\mathrm{a}}$ & 16,39 & 103 \\
\hline $\begin{array}{c}4 \mathrm{c} ; \\
32\end{array}$ & $\begin{array}{c}2,0 \times 1,5 \\
(0,8)\end{array}$ & 1050 & 169 & 16,1 & 20,2 & 20,8 & $\begin{array}{c}\text { 1Пд5Мдя } \\
3 \text { Ял1Яц }\end{array}$ & $\mathrm{I}^{\mathrm{d}}$ & 5,74 & 40 \\
\hline $\begin{array}{c}10 ; \\
103\end{array}$ & $\begin{array}{c}\text { не } \\
\text { встановл. }\end{array}$ & $\begin{array}{c}\text { не } \\
\text { встановл. }\end{array}$ & 292 & - & 39,8 & 56,6 & 10 Пд & $\mathrm{I}^{\mathrm{c}}$ & 73,47 & 1489 \\
\hline
\end{tabular}

У таких же чистих культурах псевдотсуги 63та 68-річного віку збережуваність дугласії становить на рівні 5\%. Такий низький показник зумовлений необгрунтовано високою початковою густотою культур (6,7 тис. шт. $\left.\cdot \mathrm{ra}^{-1}\right)$.

У насадженнях 25-27-річного віку найвищі середні значення діаметра і висоти зафіксовано за участі дугласії в складі на рівні 10-20\%. Поряд 3 цим, високими таксаційними показниками псевдотсуга відзначається при 50\%-ій участі в складі культур (ПД-12). Початково рідке розташування деревної породи, за умови виходу дугласії в перший ярус деревостану, забезпечує її інтенсивний ріст навіть у молодих насадженнях. Найвищих значень середніх висоти і діаметра у насадженнях 31-40-річного віку псевдотсуга досягає за 30-50\%-ої участі у складі (ПД-3з, 6 п, 1ст). У цих варіантах початкове розміщення дерев дугласії у насадженнях рідке - 5-6 × 1-2 м.

Зростання інтенсивності росту дугласії до ${ }^{\mathrm{c}}$ класу бонітету забезпечує поступове збільшення част- ки породи у складі деревостану. Збільшення інтенсивності росту хвойної породи до $\mathrm{I}^{\mathrm{d}}$ класу бонітету у насадженнях 41-60-річного віку забезпечує нагромадження значних обсягів стовбурової деревини у цей віковий період. Внаслідок високої швидкості росту, дугласія займає домінуюче положення у складі деревостану, і іï частка за обсягами нагромадження стовбурової деревини зростає до 9-10 одиниць.

Запас стовбурової деревини дугласії залежить, насамперед, від початкової густоти, збережуваності породи в культурах, участі в складі та середніх висоти і діаметра. У всіх вікових діапазонах найбільший запас стовбурової деревини нагромаджують чисті насадження псевдотсуги за рахунок більшої кількості особин на одиниці площі, хоча середні таксаційні показники породи можуть бути помітно меншими, ніж у культурах, де участь дугласії складає 30-60\%.

За результатами аналізу ходу росту модельних дерев P. menziesii, які представляють дерева груп 
слабкого, середнього і сильного росту, встановлено, що інтенсивний ріст за висотою для моделей всіх груп росту починається з 10-річного віку, однак відзначається високою інтенсивністю і в 50 років. У цьому ж віковому діапазоні спостережено також інтенсивний ріст за діаметром модельних дерев всіх груп росту, хоча і на різних рівнях. У цих же вікових межах спостережено інтенсивний ріст стовбура дугласії за об’ємом.

Беручи до уваги результати вивчення впливу густоти та участі в складі дугласії на їі таксаційні показники, наголошуємо на недоцільності створення початково густих дугласієвих насаджень. Для економії садивного матеріалу, захисту хвойної породи від низьких температур, забезпечення сприятливих умов для iii росту, пропонуємо вводити дугласію в плантаційні культури разом $з$ ялиною, що зменшить як витрати садивного матеріалу головної породи, так і створить сприятливий мікроклімат для іiі вирощування. Ялина відіграє роль допоміжної породи, є основним об'єктом проміжного користування.

3 цього погляду, важливим питанням є вибір початкової густоти штучних насаджень - як загальної, так і дугласії зокрема 3 підтриманням її в режимі, близькому до оптимального, впродовж всього періоду лісовирощування. Основним критерієм, який визначає оптимальну густоту деревостану на різних вікових етапах культивування, $є$ отримання максимального доходу за мінімальних затрат на лісовирощування. У зв'язку з цим, необхідно прийняти таку початкову густоту садіння, яка на всіх етапах розрідження деревостану, а також у віці головної рубки, забезпечила б максимальний дохід від реалізації деревини.

Порівняно 3 вологими типами, в умовах свіжого груду дугласія відзначається дещо нижчою інтенсивністю росту. Тому тут варто прийняти трохи вищу густоту насаджень як початкову, так і на послідуючих етапах вирощування. Доцільно використати рядове змішування порід за такими параметрами: схема змішування - 1р.Ял 1р.Пд; у рядах Пд обидві хвойні породи чергуються окремими садивними місцями; розміщення садивних місць - 1,5×1,0 м, в т.ч. Ял - 3,0× 1,0 м, Пд - 3,0×2,0 м; густота куль$m y p-6660$ шт. га ${ }^{-1}$, в т.ч. Пд - 1660, Ял - 5000 шт. га ${ }^{-1}$; початковий склад - 7,5Ял2,5Пд (табл. 2).

У 7-10-річному віці проводять перше розрідження по ялині, вибираючи кожен другий екземпляр породи на новорічні ялинки в чистих рядах, а також вибирають всю ялину в рядах дугласії. У типі лісових культур відбуваються деякі зміни: схема змішування - 1р.Ял 1р.Пд; розмішення садивних місиь $1,5 \times 1,0$ м, в т.ч. Ял $-3,0 \times 2,0$ м, Пд $-3,0 \times 2,0$ м; густота культур - 3300 шт. га $^{-1}$, в т.ч. Пд - 1660, Ял - 1640 шт.'га ${ }^{-1}$; кількісний склад - 5Ял5Пд.

Під час наступного етапу розріджування (1520 р.) зі складу культур вибирають всю ялину. В процесі розрідження отримують певну кількість стовбурової деревини ялини - 25-65 м³.га-1. Тип лісових культур характеризується такими параметрами: схема змішування - чисті ряди Пд; розмішуен- ня садивних місиьь - 3,0×2,0 м; густота культур 1660 шт. га $\mathrm{a}^{-1} ;$ склад - 10Пд.

Для пришвидшеного нагромадження дугласією стовбурової деревини, у 35-40 років потрібно здійснити наступне розрідження. При цьому площа живлення одного дерева зростає до $12 \mathrm{~m}^{2}$, а самі дерева після рубки розташовуються в рядах за принципом «шахівок». Тип лісових культур характеризується такими параметрами: схема змінування - чисті ряди Пд; розміщення садивних місиь - 3,0×4,0 м; густота культур - 830 шт. га $^{-1}$; склад - 10Пд.

Для стимулювання росту дугласії за діаметром та доведення кількості дерев до оптимальної величини, в 50-55-річному віці здійснюють останнє розрідження, залишивши на 1 га 415 екземплярів породи 3 розташуванням $6 \times 4$ м.

У віці головної рубки (61-70р.) отримують значну кількість деревини псевдотсуги (більше $800 \mathrm{M}^{3} \cdot \mathrm{ra}^{-1}$ ), а потенційний загальний обсяг отриманої деревини у насадженнях псевдотсуги за весь період функціонування - близько 1,3 тис. $\mathrm{M}^{3} \cdot \mathrm{ra}^{-1}$.

В умовах $D_{3}$ під час створення штучних насаджень дугласії дотримуються тих же принципів, що і в свіжих грудах, за винятком меншої початкової густоти садіння. Рекомендовано використати рядове змішування порід за такими параметрами: схема змішування - 1р.Ял 1р.Пд; у рядах Пд обидві хвойні породи чергуються окремими садивними місцями; розмішення садивних місизь - 2,0×1,25 м, в т.ч. Ял $2,0 \times 1,0(2,5)$ м, Пд - 4,0×2,5 м; густота культур 4500 шт. га $^{-1}$, в т.ч. Пд - 1000, Ял - 3500 шт. га $^{-1}$; початковий склад - 7,7Ял2,3Пд (див. табл. 2).

У 7-10-річному віці в процесі першого розрідження вибирають всю ялину в рядах псевдотсуги, а в чистих рядах - кожен другий екземпляр. У типі лісових культур відбуваються деякі зміни: схема змішування - 1р.Ял 1р.Пд; розмішення садивних місцьв: Пд - 4,0×2,5 м, Ял - 4,0×2,0 м; густота культур - 2250 шт. га ${ }^{-1}$, в т.ч. Пд -1000 , Ял -1250 шт. га ${ }^{-1}$; кількісний склад - 5,5Пд4,5Ял.

Друге розрідження здійснюють в 15-20 років i об'єктом проміжного користування є лише ялина, кількість якої знову зменшується в два рази. При цьому вже отримується невеликий обсяг (23$\left.45 \mathrm{~m}^{3} \cdot \mathrm{ra}^{-1}\right)$ дрібної стовбурової деревини. Тип лісових культур має такий вигляд: схема змімування - 1р.Ял 1р.Пд; розміщення садивних місцьь: Пд - 4,0×2,5 м, Ял - 4,0×4,0 м; густота культур 1625 шт. $\cdot \mathrm{a}^{-1}$, в т.ч. Пд - 1000, Ял - 625 шт. га $^{-1}$; кількісний склад - 6,0Пд4,0Ял.

У процесі третього розрідження (35-40 років) вибирають всю ялину і 25\% дерев дугласії з метою встановлення густоти насадження, близької до оптимальної. Тип лісових культур на цьому етапі має такий вигляд: схема змішування - чисті ряди Пд; розмішення садивних місиь - 4,0×2,5 (5,0) м; густота культур - 750 шт. га $\mathrm{a}^{-1}$; склад - 10Пд.

В 50-55 років необхідно здійснити останнє розрідження дугласії з вибиранням 25\% екземплярів породи та встановлення їх «шахівкового» розміщення 3 вирощуванням за встановлених густоти i 
розміщення дерев до віку головної рубки. Тип лісових культур наступний: схема змішування - чисті ряди Пд; розміщення садивних місиь - 4,0×5,0 м; густота культур - 500 шт. га ${ }^{-1} ;$ склад - 10Пд.
Загальні обсяги заготовленої деревини, отриманих у процесі розріджень насаджень дугласії впродовж циклу вирощування та проведення головної рубки, становлять близько 1,7 тис $\mathrm{M}^{3} \cdot \mathrm{ra}^{-1}$.

Табличя 2

\section{Таксаційна характеристика і технологічні етапи вирощування плантаційних лісових насаджень} Pseudotsuga menziesii в умовах Західного Лісостепу та Прикарпаття

\begin{tabular}{|c|c|c|c|c|c|}
\hline \multirow{2}{*}{$\begin{array}{l}\text { Таксаційні } \\
\text { показники }\end{array}$} & \multicolumn{5}{|c|}{ Віковий діапазон, років } \\
\hline & $7-10$ & $15-20$ & $35-40$ & $50-55$ & $\begin{array}{c}61-70 \\
\text { (головна рубка) }\end{array}$ \\
\hline \multicolumn{6}{|c|}{ Тип лісорослинних умов $-\mathrm{D}_{2}$} \\
\hline $\begin{array}{c}\text { К-кість дерев на } 1 \text { га, } \\
\text { шт.; (вибирається / } \\
\text { залишається) }\end{array}$ & $\frac{3360 / 1640^{*}}{-/ 1660}$ & $\frac{1640 /-}{-/ 1660}$ & $\frac{-/-}{830 / 830}$ & $\frac{-\quad / \quad-}{415 / 415}$ & $\frac{-\quad /-}{415 /-}$ \\
\hline Hs (M); & - & $7,8-10,2 /-$ & $-/ 16,2-20,4$ & $-/ 23,8-25,6$ & $-/ 27,4-29,6$ \\
\hline Ds (см); & - & $7,2-9,9 /-$ & $-/ 20,8-26,1$ & $-/ 32,8-37,6$ & $-/ 41,6-45,6$ \\
\hline Ms $\left(M^{3} / \Gamma a\right)$ & - & $25-65(45) /-$ & $-/ 200-365(280)$ & $\begin{array}{c}-/ 360-510 \\
(435)\end{array}$ & $\begin{array}{c}-/ 765-925 \\
(845)\end{array}$ \\
\hline Vs $\left(M^{3}\right)$ & - & $\begin{array}{c}0,015-0,039 \\
(0,025) /-\end{array}$ & $\begin{array}{c}-/ 0,240-0,440 \\
(0,35)\end{array}$ & $\begin{array}{c}-/ 0,872-1,232 \\
(1,05)\end{array}$ & $\begin{array}{c}-/ 1,610-2,080 \\
(1,85)\end{array}$ \\
\hline \multicolumn{6}{|c|}{ Тип лісорослинних умов - $\mathrm{D}_{3}$} \\
\hline $\begin{array}{c}\text { К-кість дерев на } 1 \text { га, } \\
\text { шт.; (вибирається / } \\
\text { залишається) }\end{array}$ & $\frac{2250 / 1250^{*}}{-/ 1000}$ & $\frac{625 / 625}{-/ 1000}$ & $\frac{625 /-}{250 / 750}$ & $\frac{-\quad / \quad-}{250 / 500}$ & $\frac{-1-}{500 /-}$ \\
\hline Hs (м); & - & $9,1-11,9 /-$ & $\begin{array}{c}19,4-21,4 / \\
17,6-21,3\end{array}$ & $-/ 25,9-27,5$ & $-/ 29,1-32,0$ \\
\hline Ds (см); & - & $10,1-12,7 /-$ & $\begin{array}{l}19,7-21,8 / \\
23,6-29,1\end{array}$ & $-/ 36,9-40,1$ & $-/ 43,2-47,7$ \\
\hline Ms $\left(M^{3} / \Gamma a\right)$ & - & $23-45(34) /-$ & $\begin{array}{c}185-250(218) / \\
85-125(105)\end{array}$ & $\begin{array}{c}-/ 300-335 \\
(316)\end{array}$ & $\begin{array}{c}-/ 805-1040 \\
(920)^{* *}\end{array}$ \\
\hline Vs $\left(M^{3}\right)$ & - & $\begin{array}{c}0,037-0,072 \\
(0,055) /-\end{array}$ & $\begin{array}{c}0,296-0,400 \\
(0,348) / 0,338- \\
0,494(0,415)\end{array}$ & $\begin{array}{c}-/ 1,205-1,494 \\
(1,36)\end{array}$ & $\begin{array}{c}-/ 1,843-2,230 \\
(2,04)\end{array}$ \\
\hline
\end{tabular}

Умовні позначення: Hs, Ds, Ms, Vs абсолютні середні значення показника;

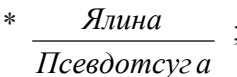

Таким чином, P. menziesii за відповідних режимів культивування в оптимальних для неї типах лісорослинних умов $\epsilon$ швидкорослим високопродуктивним деревним видом, повністю придатним для плантаційного лісовирощування. Лісовий культурфітоценоз, головною породою в якому є псевдотсуга Мензіса, представляє собою екосистему, антропогенно спрямовану на отримання максимально високих запасів деревини за відносно короткі терміни.

У випадку правильного підбору типу лісорослинних умов, найбільш високопродуктивних та стійких провенієнцій, застосуванні раціональних лісівничих прийомів під час створення насаджень за участю дугласії, можна сформувати плантаційні насадження високої продуктивності в грудових типах лісу.
Висновки. Внаслідок варіабельності грунтових умов, в яких культивують різні провенієнції P. menziesii, а також унаслідок різної технології створення і вирощування штучних насаджень, таксаційні показники деревостанів за участю цього деревного виду змінюються в широких межах.

У молодих насадженнях до 25-30-річного віку псевдотсуга поступається за інтенсивністю росту ялині і особливо - модрині. Після 35-річного віку псевдотсуга нарощує темпи росту і відставання іiі від модрини та ялини зменшується.

У свіжих грудах до 30-річного віку дугласія росте переважно за I-I ${ }^{\mathrm{b}}$, в період $31-40$ років - за I $\mathrm{I}^{\mathrm{a}}-\mathrm{I}^{\mathrm{c}}$, 41-50 - за I ${ }^{\mathrm{d}}, 61-70$ - за I $\mathrm{I}^{\mathrm{b}}-\mathrm{I}^{\mathrm{c}}$ класами бонітету. Високу швидкість росту дугласія зберігає навіть після 
100-річного віку, де бонітет ії насаджень не нижче $\mathrm{I}^{\mathrm{c}}$ класу. У вологих грудах ріст хвойної породи інтенсивніший, ніж у свіжих.

Найвищими показниками висоти та діаметра дугласія характеризується у насадженнях, де ії участь становить в середньому $30 \%$. Поряд 3 цим, найвищі запаси деревини дугласія продукує в насадженнях, де iii участь у складі максимальна.

Висока початкова густота лісових культур дугласії зумовлює сильний прояв явища диференціації рослин, що стає причиною вибирання рубками догляду значної кількості відсталих у рості екземплярів. 3 огляду на високу вартість садивного матеріалу псевдотсуги, запровадження початково густих культур є нераціональним лісівничим заходом.

Для забезпечення близької до оптимальної густоти дугласії в лісових культурах у різні вікові періоди, в умовах свіжого груду початкова густота породи повинна становити 1660 шт га $^{-1} 3$ розміщенням рослин $3,0 \times 1,0$ м; в умовах вологого груду, відповідно, 4,0×2,0-2,5 м 3 початковою густотою 1000-1250 шт·га ${ }^{-1}$. Культури дугласії потрібно створювати за участю ущільнювача (напр., ялини), початкова густота якого в культурах повинна становити 3,5-5,0 тис. шт $\cdot \mathrm{a}^{-1}$.

Отже, доцільність введення P. menziesii в насадження західного регіону України 3 метою підвищення продуктивності лісів не викликає сумніву. Швидкий ріст, нагромадження значних запасів деревини за відносно короткі терміни в чистих за складом насадженнях, висока біотична стійкість роблять деревний вид перспективним для плантаційного лісовирощування.

\section{Список літератури}

Бродович, Т.М. (1969). Лжетсуга (дугласия) в лесных насаждениях УССР. Лесоводство $u$ агролесомелиорачия, 16, 99-104 [Brodovich, Т.M. (1969). False beetle (Douglasia) in the forest plantations of the Ukrainian SSR. Forestry \& Forest Melioration, 16, 99-104 (in Russian)]

Бродович, Т.М., Шляхта, Я.М. (1979). Методические рекомендации по технологии создания промышиленных культур дугласовой пихть 8 Kapnamax. Львов: Львов. лесотехн. ин-т [Brodovich, T. M., \& Shlyakhta, Ya. M. (1979). Methodological recommendations on the technology of creating industrial crops of Douglas fir in the Carpathians. Lviv: Lviv Forestry Institute (in Russian)]

Герушинський, 3.Ю. (1996). Лісова типологія Українських Карпат. Львів: Піраміда. [Gerushynsky, Z.Yu. (1996). Forest typology of the Ukrainian Carpathians. Lviv: Piramida (in Ukrainian)]

Гірс, О.А., Маніта, О.Х., Миронюк, В.В., Свинчук, В.А., Березівський, Л.М. (2013). Лісотаксаційний довідник. Київ: Видавничий дім «Вініченко» [Girs, O.A., Manita, O.H., Myronjuk, V.V., Swingchuk, V.A., \& Berezivskyy, L.M. (2013). Forest Inventory Directory. Kyiv: Vinichenko Publishing House (in Ukrainian)]
Горошко, М.П., Миклуш, С.І., Хомюк, П.Г. (2004). Біометрія. Львів: Камула [Goroshko, M.P., Myklush, S.I., \& Khomyuk, P.G. (2004). Biometrics. Lviv: Kamula (in Ukrainian)]

Дебринюк Ю.М. (2013). Псевдотсуга Мензіса в Україні: розповсюдження, лісівничо-таксаційна характеристика та перспективи культивування. Лісівниитво $i$ агролісомеліорація, 122, 24-31 [Debryniuk, Yu. M. (2013). Pseudotsuga menziesii in Ukraine: distribution, forestry and assessment characteristics and prospects of cultivation. Forestry \& Forest Melioration, 122, 24-31 (in Ukrainian)]

Дебринюк, Ю.М. (2018). Ресурсний потенціал та перспективи плантаційного лісовирощування в Україні. Основні проблеми йтенденції подальшого розвитку лісового господарства в Українських Kapnamax: матеріали міжнарод. наук.-практ. конф., м. Івано-Франківськ, 4-6 жовтня 2018 р., 72-79 [Debryniuk, Yu. M. (2018). Resource potential and prospects of plantation afforestation in Ukraine. In The main problems and trends of further development of Forestry in the Ukrainian Carpathians, 72-79. IvanoFrankivsk, Ukraine: Ukrainian Scientific-Research Institute of Mountain Forestry (in Ukrainian)]

Дебринюк, Ю.М. (2003). Ріст і продуктивність Pseudotsuga menziesii (Mirb.) Franco в лісових культурах Українського Розточчя. Науковий вісник Укр. держ. лісотехн. ун-ту, 13.2, 21-32 [Debryniuk, Yu.M. (2003). Growth and productivity of Pseudotsuga menziesii (Mirb.) Franco in forest crops of Ukrainian Roztocze. Scientific Bulletin of the Ukrainian State Forestry University, 13.2, 21-32 (in Ukrainian)]

Дебринюк, Ю.М. (2011). Технологічні аспекти створення і вирощування плантаційних лісових культур Pseudotsuga menziesii (Mirb.) Franco у західному регіоні України. Лісівництво $i$ агролісомеліорачія, 118, 142-148 [Debryniuk, Yu.M. (2011). Technological aspects of creation and cultivation of plantation forest crops Pseudotsuga menziesii (Mirb.) Franco in the western region of Ukraine. Forestry \& Forest Melioration, 118, 142-148 (in Ukrainian)]

Калинин, М.И. (1983). Формирование корневой системы деревьев. Москва: Лесная промышленность [Kalinin, M.I. (1983). Formation of the root system of trees. Moscow: Forestry industry (in Russian)]

Матяш, В.В. (1988). Биология репродукции и семенная продуктивность лжетсуги Мензиса в Лесостепи Украины. Интродукция и акклиматизачия древесных растений, 9, 21-24 [Маtyash, V.V. (1988). Biology of reproduction and seed productivity of Pseudotsuga menziesii in the Forest-steppe of Ukraine. Introduction and acclimatization of woody plants, 9, 21-24 (in Russian)]

Остапенко, Б.Ф., Ткач, В.П. (2002). Типологія лісу. Харків: Харківський державний аграрний університет [Ostapenko, B.F., \& Tkach, V.P. (2002). Forest typology. Kharkiv: Kharkiv State Agrarian University (in Ukrainian)]

Хмилевский, В.М.(1987). Повышение продуктивности лесов Лесостепи Украины путем интродукции дугласии зеленой: автореф. ... канд. с.-х. 
наук: 06.03.01 / УкрНДІЛГА. Харьков, 23 с. [Khmilevsky, V.M. (1987). Increasing the productivity of forests of the Forest-steppe of Ukraine by introducing green douglas (Doctoral dissertation, Ukrainian Research Institute of Forestry and Forest Melioration, Kharkiv, Ukraine) (in Ukrainian)]

Шляхта, Я. М. (1991). Итоги интродукции дугласии в лесных насаждениях Украины. Folia dendrologia, 18, 245-254 [Shlyakhta, Ya. M. (1991). The results of the introduction of Douglas in the forest plantations of Ukraine. Folia dendrologia, 18, 245-254 (in Russian)]

Cole E., Lindsay A.R., Newton M., \& Bailey J.D. (2018). Eight-year performance of bareroot Douglasfir and bareroot and plug western larch Seedlings following herbicide applications, northeast Oregon, USA. New Forests, 49 (6), 791-814. https://doi. org/10.1007/s11056-018-9653-5

Bastien, J.-C., Sanchez, L., \& Michaud, D. (2013). Douglas-Fir (Pseudotsuga menziesii (Mirb.) Franco). Chapter 7. In: Pâques Luc E., 10427J, dir., Forest tree breeding in Europe. Current state-of-the-art and perspectives (pp. 325-369). Managing Forest Ecosystems, 25. Dordrecht, NLD: Springer. 527 p., https://doi.org/10.1007/978-94-007-6146-9_7. https://prodinra.inra.fr/record/196485

Burgbacher, H., \& Greve, P. (1996). 100 Jahre Douglasienanbau im Stadtwald Freiburg. [100 years of Douglas fir cultivation in the Freiburg city forest] Allgemeine Forstzeitung, 51, 1109-1111 [in German]

Da Ronch F., Caudullo, G., \& de Rigo, D. (2016). Pseudotsuga menziesii in Europe: distribution, habitat, usage and threats. In European Atlas of Forest Tree Species (pp. 146-147), Publisher: Publication Office of the European Union, Luxembourg

Kupka, I., Podrázský, V., \& Kubeček, J. (2013). Soilforming effect of Douglas fir at lower altitudes. Journal of Forest Research, 59, 345-351. https://doi. org/10.17221/27/2013-JFS

Meuer, H. (1953). Über die Beweggründe für die Anlage von Douglasien-Plantagen [About the motivation for the establishment of Douglas fir plantations] Allgemeine Forstzeitung, 8 (6), 101-104 [in German]

Moser, B., Bachofen, Ch., Müller, D. J., Metslaid, M., \& Wohlgemuth, T. (2016). Root architecture might account for contrasting establishment success of Pseudotsuga menziesii var. Menziesii and Pinus sylvestris inCentralEuropeunderdryconditions. Annals of Forest Science, 73 (4), 959-970. Retrieved from https://link.springer.com/article/10.1007/s13595-0160574-1

Otto, H.-J. (1972). Zu den Standortansprüchen der Douglasie. [About the location requirements of the Douglas fir] Forstarchiv, 43, 62-65 [in German]

Podrázský, V., Remeš, J., Hart, V., \& Moser, W.K. (2009). Production and humus form development in forest stands established on agricultural lands. Kostelec nad Černými lesy region. Journal of Forest Science, 55 (7), 299-305 https://doi. org/10.17221/11/2009-JFS

Podrázský, V., Čermák, R., Zahradník, D., \& Kouba, J. (2013). Production of Douglas-fir in the Czech
Republic based on national forest inventory data. Journal of Forest Science, 59 (10), 398-404. https:// doi.org/10.17221/48/2013-JFS

Podrázský, V., Zahradník, D., Pulkrab, K, Kubeček, J., \& Peňa, J.F.B. (2013). Hodnotová produkce douglasky tisolisté (Pseudotsuga menziesii /Mirb./ Franco) na kyselých stanovištích Školního polesí Hůrky, Písecko [Production value of Doulas-fir (Pseudotsuga menziesii /Mirb./ Franco) on acid sites of the School Forest Hůrky, Písek region] Zprávy lesnického výzkumu, 58, 226-232 [in Czech]

Šika, A., \& Vinš, B. (1980). Rust douglasku v lesnich porostech CSR [Douglas fir growth in forest stands of Czechoslovakia] Pr. VULHM, 28, 73-95 [in Czech]

\section{Pseudotsuga menziesii (Mirb.) Franco as a promising tree species for forest plantations in the western region of Ukraine}

\author{
lu. Debryniuk
}

Douglas-fir is an introduced species with a pronounced specific character of growth - it grows relatively slowly at a young age, but with a subsequent acceleration of the growth rate and maintaining its high intensity for a long period of time - one hundred or more years. Due to the variability of soil conditions in which Douglas fir of various provenances are cultivated, as well as due to different technologies of establishing and cultivating plantations of this species, the biometric indexes of forest stands with the participation of this coniferous species vary widely.

Particularly favorable for the growth of Pseudotsuga menziesii are moist fertile beech forest types and spruce forests of the Pre-Carpathian region, where already, starting from the age of 20, Douglas fir exceeds spruce in height and diameter, and the growth retardation from larch is much less than in the conditions of the Western Forest-steppe (within 10-15\%). The density of Douglas fir in both young and middle-aged and mature stands plays a significant role in the stem wood accumulation by the species. The most productive plantations are characterized by the uniform distribution of trees over the area and high crown density.

The participation of Pseudotsuga menziesii in the composition that provides the maximum amount of wood accumulated by the species depends on the age of the plantations. In young plantations, the high share of Douglas fir in the tree composition is not accompanied by high stocks of wood, while in plantationss older than 40 years, the highest stock of wood of this

\footnotetext{
Iurii Debryniuk - full Member of the Forestry Academy of Sciences of Ukraine, Academician-Secretary of the Ukrainian Forestry Academy of Sciences, Doctor of Agricultural Sciences, Professor of the Department of Forest Crops and Forest Selection. Ukrainian National Forestry University. General Chuprynka str., 103, Lviv, 79057, Ukraine. Tel.: 032-235-30-12, + 38-067-19578-36. E-mail: debrynuk_ju@ukr.net. ORCID: https://orcid. org/0000-0002-0994-349X
} 
species is formed in pure stands. At the same time, the highest indexes of the height and diameter of Douglas fir are characteristic of plantations, where its share is on average $30 \%$. For mixed plantations of 35 years of age, with a $60 \%$ share of Douglas fir in the stand composition, a close to the optimal spacing of the species can be considered as $4 \times 3 \mathrm{~m}$; in such a case, there is a good cleaning of trunks from branches (natural pruning), the compact crown formation with an average area of $12-15 \mathrm{~m}^{2}$.

After 35 years of age and with the participation in the stand composition of more than $60 \%$, Douglas fir significantly increases the intensity of growth, its density increases in all the studied stands, as a result of which the stock of stem wood increases. When growing Douglas fir in plantations, you should not expect to obtain significant volumes of wood of this species until the age of 30 to 40 years old. The task is to grow plantations in the optimal density mode, which will provide a very significant increase in the growth intensity of the species after the indicated age, and by the age of 50-60, wood standing volume will reach $700 \mathrm{~m}^{3} \cdot \mathrm{ha}^{-1}$ and more.

Douglas fir forest plantations should be grown pure in composition, which will eliminate the negative impact on the species at a young age of other fastergrowing tree species, this will realize the potential for rapid growth and facilitate the crop tending. In order to protect Douglas fir from winter frosts, it is advisable to introduce an auxiliary tree species, for example, Norway spruce, into its plantations. Douglas fir reaches the highest classes of quality in plantations at the age of 40 to 60 years old at various initial schemes of spacing of planting spots $-2.0-6.0 \times 0.8-2.0 \mathrm{~m}$.

In pure plantations of Pseudotsuga menziesii, under conditions of fresh fertile site type, when creating plantations of the species, the initial density should be taken as 1.5-2.0 thousand pcs / ha (taking into account the auxiliary species, the total density will be 6.6 thousand pcs / ha). In moist fertile site types, the growth rate of Pseudotsuga menziesii is slightly higher, so the initial density of the species should be slightly less (1.0-1.5 thousand pieces / ha), and taking into account the auxiliary species - 4.5-5.0 thousand pcs / ha.

Key words: biometric indexes; growth course; density; participation in the composition; plantations; Western Forest-Steppe; Pre-Carpathian region.

\section{Pseudotsuga menziesii (Mirb.) Franco как перспективный древесный вид для плантационных лесных насаждений западного региона Украины}

\section{Ю.М. Дебринюк'}

Pseudotsuga menziesii является интродуцентом с ярко выраженной спецификой роста - сравнительно медленнорастущая в молодом возрасте, но с последующим увеличением скорости роста и поддер- жанием его высокой интенсивности в течение длительного периода времени - до ста и более лет.

В молодых насаждениях до 25-30-летнего возраста псевдотсуга поступается по интенсивности роста ели и особенно - лиственнице. При этом преимущество лиственницы по высоте и диаметру может составлять два раза и более. Если в чистых культурах псевдотсуга растет по I ${ }^{\mathrm{a}}$ и I $\mathrm{I}^{\mathrm{b}}$ классам бонитета, в дубово-дугласиевых - по I ${ }^{a}$, в дугласиево-еловых по I, то в дугласиево-лиственнично-еловом - по II классу бонитета, тогда как ель растет по $\mathrm{I}^{\mathrm{b}}$, а лиственница - по Ic и выше классам бонитета.

Долевое участие P. menziesii в составе, который обеспечивает максимальные объемы стволовой древесины, зависит от возраста насаждений. В молодых насаждениях высокое участие дугласии в составе не сопровождается высокими запасами древесины, тогда как в культурах старше 40 лет высокий запас древесины порода формируется именно в чистых по составу насаждениях. При этом самыми высокими показателями высоты и диаметра дугласия характеризуется именно в насаждениях, где ее участие составляет в среднем $30 \%$.

Для 35-летнего возраста в смешанных культуpax c 60\%-ым участием в составе, близким к оптимальному можно считать размещение дугласии $4 \times 3$ м; при этом происходит хорошее очищение стволов от сучьев, формирование компактной кроны при средней ее площади в пределах 12-15 м². После 35 -летнего возраста и при участии в составе более $60 \%$ дугласия существенно увеличивает интенсивность роста, и увеличение ее участия в составе насаждений сопровождается увеличением запаса стволовой древесины.

При плантационном культивировании дугласии приоритетом является выращивание насаждений в режиме оптимальной густоты, что обеспечивает значительное усиление интенсивности роста породы после 30-40 лет, и уже к 50-60 годам запасы древесины достигают $700 \mathrm{~m}^{3} \cdot \mathrm{ra}^{-1}$ и более.

Высоких классов бонитета псевдотсуга достигает в насаждениях 40-60-летнего возраста при различных начальных схемах размещения посадочных мест - 2,0-6,0×0,8-2,0 м.

Ключевые слова: таксационные показатели; ход роста; густота культур; участие в составе; плантационные насаждения; Западная Лесостепь; Прикарпатье.
Дебринюк Юриц̆ Михайлович - академик Лесной академии
наук Украины, академик-секретарь ЛАН Украины, доктор
сельскохозяйственных наук, профессор кафедры лесных культур
и лесной селекции. Национальный лесотехнический университет
Украины, ул. Генерала Чупринки, 103, г. Львов, 79057, Украина.
Teл.: 032-235-30-12, +38-067-195-78-36. E-mail: debrynuk_ju@,
ukr.net ORCID: http://orcid.org/0000-0002-0994-349X 